\section{Dr. Peter T. Bobrowsky}

\section{IUGS Vice President}

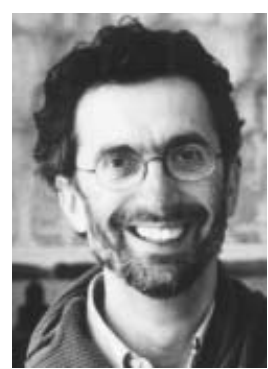

"I am extremely thrilled to receive an income for my hobby. Quaternary research is clearly my passion, and to be given the opportunity to pursue this interest daily and also recognize this activity as a career is incredibly fortunate" is a phrase often quoted by Peter Bobrowsky, Ph.D., P.Geo. After some 25 years of research in Quaternary studies, Peter's hobby continues to be satisfied with every new day of work.

Born in 1955 to Ukrainian immigrant parents in Edmonton, Alberta, Canada, Peter soon adopted the philosophy of his family, which included an appreciation for educational opportunities offered in a country like Canada. The youngest in a family of three children, Peter eventually entered the University of Alberta and completed, in 1977, a Bachelor of Arts Honors degree with a major in Anthropology and minor in Geology. It was during this program that he expanded his Quaternary interests to include geosciences. At the time, he focused on becoming an archaeologist, but recognized early on that a sound background in earth sciences (geology and geography) was critical to communicate with interdisciplinary colleagues, as well as to better interpret complex stratigraphical and sedimentological processes of archaeological site formation. Set on entering graduate studies in archaeology, Peter felt that his interdisciplinary background remained weak for advanced research. As he puts it, "I remember being overwhelmed by the wisdom of graduate students who could speak authoritatively on very specialized subject matters. I so much wanted to pursue graduate work, but felt that to do so successfully, I would have to enhance my multidisciplinary repertoire". Instead of immediately pursuing graduate studies, Peter obtained a second undergraduate degree, this time a Bachelor of Science degree. It was then that Peter first met Dr. Nathaniel Rutter (Prof. of Geology) who would eventually become his primary mentor and colleague in geology for years to come. "I remain indebted to Prof. Rutter for his continued support and tutelage in matters related to science". Although an undergraduate student, majoring in geology at the time, he completed several graduate level courses in Quaternary geology. It was during this degree program that he also added relevant Quaternary courses in zoology, biology, geography, dendrology, etc. to complement his primary focus on geology as well as further expanding his interdisciplinary interests.

After his B.Sc., Peter moved to Vancouver to complete his Master of Arts degree in Archaeology at Simon Fraser University. He studied with two brilliant young professors, zooarchaeologist Dr. Richard Casteel and archaeo-statistician Dr. Jack Nance. His M.A. dealt with quantitative methods for the paleoecological study of Quaternary aged mollusks. Upon graduation, Peter returned his full attention toward geological studies in 1982 when he was awarded the prestigious Ralf Steinhauer Award for Distinction; funding which enabled him to return to the Department of Geology at the University of Alberta to start his doctoral studies on the sedimentology and stratigraphy of Cenozoic deposits in the Northern Rocky Mountain Trench of British Columbia. During the next six years, working on his $\mathrm{PhD}$, Peter shared his interests with 13 other graduate students under the supervision of Dr. Rutter and dozens of other Quaternary graduate students in geography, zoology, entomology and other departments. Now some 20 years later, Peter appreciates this graduate camaraderie and regularly interacts with these other students who have since become senior Quaternarists in academia, industry and government across the globe.

In 1988, Peter was awarded a Post Doctoral Fellowship, and moved to Sidney, British Columbia to pursue research in the blossoming new field of West Coast neotectonics under the supervision
Canada. Within a year he accepted a permanent position in the neighboring city of Victoria to become the provincial Quaternary geologist with the BC Geological Survey Branch. At the same time he met and married his wife Theresa. Regarding this latter memorable event, Peter says "the wedding day ended successfully, but the marriage ceremony was briefly interrupted by near hurricane force winds, which partially destroyed the church in question and forced the evacuation of all wedding guests to a nearby structure!" During the next several years, and through a series of publications, Peter and Clague greatly enhanced the inventory, history, knowledge and effects of paleoseismic data for western Canada. This work remains one of his most significant contributions to science. According to Peter, "John Clague has always been an excellent teacher, reliable colleague and good friend".

While continuing with his position at the BCGS, Peter became an Adjunct Professor at Simon Fraser University, Vancouver and the University of Victoria, Victoria. For the last seven years at the University of Victoria he has annually taught a senior Quaternary geology course as well as directed study courses on air photographic interpretation, environmental geology, slope stability, and urban geology. He currently supervises five graduate students whose thesis topics reflect Peter's broad interests: paleotsunamis of BC, placer diamonds in Guyana, landslide geotechnics in central BC, till geochemistry of glaciated terrain, and medical geology of Victoria.

During his tenure as a professional geologist, Dr. Peter Bobrowsky has published some 200 articles, books, maps, reports and abstracts on a variety of subjects. His primary responsibilities to the BCGS are aggregate resources, drift prospecting and geohazards. Research in sand and gravel lead to the 1998 publication of a very successful edited volume entitled Aggregate Resources: a global perspective (A.A. Balkema). His interest in till geochemistry has now evolved to include the growing field of medical geology. Last year he and his colleague Dr. Olle Selinus (SGU, Sweden) successfully initiated IGCP Project \#454 on medical geology. A long-standing interest in a variety of geohazards and engineering geology prompted Peter to publish a book in 2001 entitled Geoenvironmental Mapping: method, theory and practice (A.A. Balkema).

In 1993, as Local Organizing Committee Chair for the Biennial Meeting of the Canadian Quaternary Association, he met Dr. Ed de Mulder (Pres. of IUGS). That meeting on Applied Quaternary Geology allowed Peter and Ed to expand their shared professional interests and to begin their current long-standing friendship. "My foray into international geosciences has been facilitated by the remarkable guidance of de Mulder". In 1994, Peter became Secretary General of COGEOENVIRONMENT, a post he held for the next six years until 2000 when, during the IGC in Rio de Janeiro, he was elected Vice President of IUGS. This most recent appointment highlights a number of other accomplishments including VP and President of the Canadian Quaternary Association, President of the Pacific Section of the Geological Association of Canada, Editorial Board of Quaternary International, International Director of the Canadian Geoscience Council, international co-leader of IGCP 454, Canadian co-leader of IGCP 425, member of CNC-INQUA, CNC-IGCP, working groups on Geoindicators, Medical Geology, steering committee of the Canadian Climate Impacts and Adaptation Network Landscape node (C-CIARN), etc.

Peter Bobrowsky remains an avid geological explorer traveling thousands of kilometers around the world, often visiting several different countries per year. His home life in Victoria is shared with his wife and two incredible Labrador retrievers (Oreana and Killian).

\section{Address:}

Dr. Peter T. Bobrowsky

Ministry of Energy and Mines

B.C. Geological Survey Branch

PO Box 9320, Stn Prov Govt

Victoria, British Columbia V8W 9N3

CANADA

Tel.: +1-250-952 0395

Fax: +1-250-952 0381

E-mail: peter.bobrowsky@gems7.gov.bc.ca 